\title{
The Importance of Maslahah Orientation in Sharia Institutions
}

\author{
Primasatria Edastama ${ }^{1}$ \\ ${ }^{1}$ Fakultas Ekonomi dan Bisnis Universitas Esa Unggul, Jakarta \\ JI. Arjuna Utara No.9, Kebon Jeruk, Jakarta Barat, 11510 \\ e-mail: primasatria@esaunggul.ac.id ${ }^{1}$
}

Author Notification

17 April 2021

Final Revised

7 May 2021

Published

8 May 2021

To cite this document :

Edastama, P. (2021). The Importance of Maslahah Orientation in Sharia Institutions. Aptisi Transactions on Management (ATM), 5(2), 180-190.

DOI :

https://doi.org/10.33050/atm.v5i2.1595

\begin{abstract}
The research from the paper entitled "The Importance of Maslahah Orientation in Sharia Institutions" aims to see how important a sharia institution is in orienting its institution to a benefitbased orientation. The research in this paper which discusses the importance of maslahah orientation in sharia institutions is motivated by the lack of attention to several existing sharia institutions towards some of the principles and objectives of the basics of sharia. Lack of some principles and basic objectives, namely to be able to get benefits and in this study, it will also be seen if the effect of benefits on satisfaction and loyalty in Islamic institutions. This study also will use several structural equation modeling methods as data processing techniques. Data collection in this paper was carried out by using questionnaires distributed to customers in Islamic institutions and in this study it was found that orientation to maslahah is a very important factor in building loyalty to several sharia institutions. In addition, orientation towards maslahah also really needs to be improved. as a means of increasing customer satisfaction. Then the results of this study are also expected to be the basis for sharia institutions to focus more on maslahah orientation for their institutions following the basic principles of sharia itself.
\end{abstract}

Keywords: Maslahah, customer loyalty, satisfaction, Islamic institution marketing

\section{Introduction}

Based on the opinion of previous scholars, Maqasid Sharia is a goal that needs to be fulfilled in order to become a Muslim in order to gain mercy and benefit in this world and the hereafter. Since the beginning, the understanding and application of Maqasid Sharia was aimed at the field of law and policy, adjusted to the understanding of the meaning of Maqasid Sharia as mentioned above. Then this Maqasid Sharia became a concept that was applied in many other fields such as economics[1], politics and culture with the expectation of benefits [2].

For this reason, researchers conducted research on the development of an Islamic marketing orientation using the basic framework of Maqasid Sharia. As mentioned above that Maqasid Syariah is an ideal concept which is very flexible which can be applied to many areas. In this case in marketing strategy. The use of Maqasid Sharia because the purpose of this idea is to benefit from the world and the hereafter. Promoting these benefits can be carried out research on the development of an Islamic marketing orientation using the basic framework of Maqasid Sharia. As mentioned above that Maqasid Syariah is an ideal concept which is very flexible which can be applied to many areas. In this marketing strategy. The use of the Maqasid Sharia strategy 
is due to the idea that the aim of this idea is to benefit from the world and the hereafter. Promoting these benefits can attract more customers [3].

Maslahah in context is the ultimate goal of Maqasid Syariah itself, or it can be said that Maqasid Sharia is Maslahah. In the development of theories related to Islam, many scientists use this maslahah as a basis for building theoretical concepts. This Maslahah consists of five factors, namely protection of religion, protection of life, intellectual protection, protection of descent, and protection of wealth, these are also often referred to as the basic needs of a Muslim [4]. From this explanation, it appears that the similarity between Maslahah and Maqasid Sharia, according to Imam Ghazali also states that Maqasid Sharia can be divided into three forms of needs where the basic needs consist of the need for protection of religion or faith, life, intellectuality, descent, and wealth.

The following is an illustration of the importance of maslahah orientation in Sharia Institutions. In some studies, the lack of loyalty and satisfaction in Sharia Institutions is caused by several factors. For example, one of the factors that caused doubts about Islamic banking was the lack of focus on banking attention on the development of the small and micro sectors, according to [5] Islamic banking has not fully fulfilled one of its tasks and its main vision is to be able to build small and micro sectors, where Islamic banking is still more oriented towards the middle and upper sectors. This shows that Islamic banking is still too profit-oriented, not using the actual orientation expected of an Islamic institution that is of interest to the public and Maslahah. This means that a lack of orientation will create a lack of loyalty to customers. In fact, this loyalty is very important because customer loyalty will encourage the sustainability of the company. The more loyal customers for the company's products, the longer the company's life will be. From the description above, it can be seen that loyalty is a very important factor for the company. The company will strive to be able to build loyalty to these consumers. By looking at the description above, this study will discuss the effect of maslahah orientation in the company on customer satisfaction and loyalty [6].

\section{Sharia Maqasid}

Maqasid Sharia can be translated as the goal or objective of Sharia, where maqasid is the plural form of maqsad which can also be expressed as a straight path, balance and justice, and set direction, while Sharia is a law or rule that directs every aspect of the Islamic belief system, the relationship between humans and Allah, and the relationship between humans and the moral and ethical system forms in Islam [7]. Maqasid Sharia will also cover all the objectives of Islamic law or rules, such as standards and criteria, values and instructions so that the rules can provide solutions to problems faced by every human being, or in short it can be said that the Maqasid Sharia as objectives will be discussed by the formation of rules and Islamic Sharia law [8] . In addition, Maqasid Sharia is the objective, objective, or purpose of implementing laws or rules in Islam which can be found in the basic philosophy of Islamic law which can be manifested in various ways such as righteous deeds, avoidance of chaos, wisdom of an action, conformity to legal analogies, basic from preference to law, to the basis of continual principles, and many other ways of shaping law through ijtihad. Therefore, it can be concluded that the Maqasid Sharia is a tool that can be used to achieve the goal of Islamic Sharia is to get to the afterlife, where the Maqasid Sharia is the framework that will show the direction.

According to [9], Maqasid Sharia can be divided into several dimensions according to certain classifications, namely:

1. Classification based on need.

2. The scope of objectives to be achieved.

3. The scope of people involved.

4. The level of scope of objectives.

ATM Vol 5, No. 2 July 2021: 180-190 
The classification based on needs is a general classification based on the classification which is divided into basic needs (Dharuriah), needs (Hajjiat), and luxury needs (Tahsiniat). Furthermore, the basic needs will also be divided into the need for protection of faith, life, mind, ancestry, and wealth and some add honor. Basically, this basic need is a human need to live righteously. Furthermore, the classification based on the scope of objectives can be divided into three dimensions, namely:

1. General maqasid which includes all Islamic law, such as justice.

2. Specific Maqasid, namely Maqasid which only covers 1 part of Islamic law such as child care in family law, prevention of crimes in crime.

3. Some Maqasid, namely Maqasid which is the purpose of each text in Islamic law.

Sharia maqasid can also be divided according to the scope of the number of people involved such as just a community, country or even the whole world. The division of maqasid based on a certain scope will make maqasid Sharia more flexible so that its application will be more precise and easier to reach its target . Based on this, it can be said that Maqasid Sharia can also be applied to Sharia institutions.

Until now, the implementation of Maqasid Sharia in Sharia Institutions is actually quite a lot, but the majority of research and studies on Islamic Maqasid are still aimed at the sector or the financial sector of Islamic banking itself[10]. Several studies focus on the study of marketing or business strategies that implement maqasid Syariah itself. However, through the discussion of maqasid regarding Islamic finance, it can be seen that the actual assessment of Sharia in banking is not only related to halal products either in a procedure or mechanically, but also requires a commitment from Islamic values. Through this explanation it can also be concluded that to be able to form Islamic law can be done through ijtihad, this is to get a more practical result.

\section{Orientation Maslahah}

The element of the objective of the Maqasid Syariah according to [9] is Maslahah orientation. Maslahah has become a fundamental discussion in the formulation of Islamic law where maslahah is a form of goal to be achieved through this law. Before discussing the need to understand the maslahah orientation in the management of a sharia institution, Kotler stated that in marketing, a basic philosophy is needed which will be the main orientation for a company in the market.

So far there are several forms of marketing orientation that have been commonly used, namely,

1. Production concept. This is the oldest philosophical concept that guides sales. Stating that consumers will like the products that are available and the prices are affordable. With this concept, management must focus on increasing the efficiency of production and distribution. The production concept is still a useful philosophy in some situations.

2. Product concept. Stating that consumers like products that offer the best quality, performance, innovative features. Based on this concept, the marketing strategy focuses on continuous product improvement.

3. The concept of sales. Many companies follow the sales concept, which states that consumers will not buy a company's product unless the product is sold in large-scale sales and promotional efforts. This concept is usually previewed on items that are not sought after items that consumers would not consider purchased under normal circumstances, such as insurance or blood donations. The industry has to track prospects and sell products based on the benefits of the product. However, this aggressive selling carries a high risk. This concept is based on the creation of sales transactions and not long-term profitable customer relationships.

The Importance of Maslahah Orientation in Sharia Institutions (Primasatria Edastama) 
4. Marketing concept. Stating that achieving organizational goals depends on knowing the needs and wants of the target market and providing the desired satisfaction better than competitors [11]. With this concept, customer focus and value is the path to sales and profit. The philosophy is "make and sell" centered on the product. The marketing concept is a customer centered "feel and respond" philosophy. This concept is seen in marketing not as a hunting activity but as a gardening activity. The job is not finding the right customer for your product, but finding the right product for the customer.

5. Social-Insightful marketing concept. The social-insightful concept of marketing questions whether the concept of pure marketing already sees a possible conflict between short-term and consumer desires and the long-term welfare of the consumer. Does the company that is able to meet the current needs and wants of the target market always do what is best for the consumer in the long run? Social-insightful marketing concept states that a marketing strategy must be able to provide value to customers in a way to maintain or improve the welfare of consumers and society.

In this study, an orientation concept will be used which will be based on Maslahah, in other words the company will be more concerned about the benefits of customers and the wider community than only focusing on company profits. Etymologically, maslahah means to do good, right or in accordance with the truth. When formed into the form of the noun itself it means goodness or something useful. Technically, Maslahah can be interpreted as a legal purpose or the meaning of a relationship between them. According to Al-Ghazali, being referred to as Maslahah is an act of providing protection and security for the objectives of Islamic Sharia, which can be summarized in five things, namely protection of faith, life, reason, descent and wealth. Thus, Maslahah can also be called a benefit or interest that is necessary in the maintenance of Islamic law or Sharia by humanity through five things.

Based on several researchers, maslahah divided into three types of maslahah, namely:

1. Maslahah Muctabarah, namely Maslahah that applies in the Qur'an but still requires the next ljmaa in its interpretation.

2. Maslahah Mulghah, maslahah which clearly usually takes the form of orders or prohibitions in the Qur'an.

3. Maslahah, namely Maslahah whose situation and conditions are still unclear and also cannot be done is still unclear.

This type of premish is a type of maslahah that is usually studied widely because it does require more judgment to be able to determine whether something is possible or not done. According to Al-Shanqiti, Maslahah itself can be divided according to several classifications:

1. The classification is based on consequences, in this classification the Maslahah can be divided into five categories, namely, protection of religion, protection of the soul, protection of reason, protection of heredity, and protection of wealth.

2. Classification based on the level of Maslahah, in this classification Maslahah can be categorized into three, namely Dharuriah, namely where this is a basic maslahah or it can be said as Maslahah in the form of needs, Hajjiah is a maslahah which is still in the form of need but this is more for convenience, which means that if this is not achieved an individual will still live well, and the highest Tahsiniah is Maslahah, this maslahah can also be said to be a luxurious maslahah so that the individual achieves the best.

From the description above, it appears that the understanding of Maslahah is very similar to the understanding of Maqasid Sharia. This is very possible because it implies that Maqasid Sharia is maslahah itself. As has been discussed that the Maqasid of Sharia is the objective of 
Sharia, and in the above explanation it is also found that the expected goal of the implementation of Sharia is to obtain maslahah.

\section{Loyalty}

[12] Stated that the main goal of marketing is to build loyalty, which will further spread the customer. For marketing-oriented banks, this issue has become a well-recognized paradigm to replace the traditional and art-oriented business paradigm. This paradigm in practice is able to generate customer dissatisfaction which in turn affects customer loyalty which is decreasing [13]. Loyalty is defined as the attitude shown by the customer to the Bank. The client will show his loyalty if the bank is able to provide satisfaction to its customers. A loyal customer is a person who retrades with the same bank and maintains a positive attitude towards administration in the future [14].

Loyalty is Customer behavior which will be known if the customer has used the product offered by the Bank, loyal customer is a customer who has a deep commitment to repurchase and subscribe to a product or service consistently in the future, so that it can cause repeated transactions with the same company even though the influence of the situation and the various marketing efforts that have the potential to cause a company movement [15].

Based on customer loyalty [16] will give birth to customer behavior and actions such as:

1. Customer behavior that provides recommendations to invite others to make transactions or use products.

2. Customers will carry out transaction activities or use all forms of services offered by the company.

3. Customers will make the company their first choice in using financial services.

4. Word of mouth is customer behavior to discuss good things about the company's products to others.

[17] found that consumer loyalty is an important determinant of gaining a sustainable competitive advantage. The importance of customer loyalty is a direct result of the many advantages to product / service marketing efforts. First, loyal customers tend to influence competition [18]. Second, [19] stated that trust in brands is a consequence of customer loyalty. Therefore, the fact that loyal customers feel confident and satisfied with the brands they choose, they tend to be involved in finding information about competitors [20], so they are more likely to retain the brands they like.

According to [21] keeping customers is cheaper for the company than to get new venture; Which makes customer loyalty a plus for the company. The cost of serving loyal customers is also not as fast as when the company served new customers [20]. Due to the fact that they are loyal to the brand, they also tend to be less price sensitive, thus increasing the profit margins on the product .

Lastly, loyal customers are profitable because of their desire to do word of mouth recommendations, where in the practice non-loyal customers do not exist or can even get negative words out of their mouth [1]. Positive Recommendations assist the company in acquiring new customers and retaining existing ones. It is clear that increasing customer loyalty gives good results for the company, brand, product, or service.

\section{The influence of Maslahah orientation on loyalty}

Basically there is no direct research related to Maslahah's influence on satisfaction and loyalty. However, based on the meaning of the maslahah itself both etymologically and technically, Maslahah must have a positive impact. The impact that will be discussed is of course customer satisfaction. Indirect community protection is a form of special and personal attention from companies to customers. Thus, the higher ability of a company to achieve Maslahah 
protection will result in a higher level of customer satisfaction. As has been suggested that high satisfaction will form loyalty to customers. There are several studies that intersect with the effect of the benefits of satisfaction and loyalty as follows, revealed that there is a lot of concern and acceptance of marketing applications based on Islamic rules both on the side of entrepreneurs and the general public, but varies widely depending on people's religious educational background.

Furthermore, found that religiosity is the main mediating factor that drives consumer behavior in Islamic banking services in Malaysia [1]. In a different study, found that general Islamic values such as halal / Haram products, honesty, humanity, and concern for religious activities such as (prayer times) provide a more positive perception of acceptance of services provided to Muslim consumers in Indonesia [22]. And findings [23] reveal that adherence to Islamic regulations in the banking sector is very important for the development of Islamic banking marketing relationships.

With the explanation, the hypothesis will be formed as follows:

$\mathrm{H} 1$ : There is a problem orientation influence on satisfaction

$\mathrm{H} 2$ : There is an effect of maslahah orientation on loyalty

$\mathrm{H} 3$ : There is a problem orientation of influence on loyalty through satisfaction

\section{Research Method}

This research is a hypothesis testing research that aims to test hypotheses derived from existing theories and research, where in the study that will discuss the effect of orientation on issues for loyalty there are 4 hypotheses. This study will use variables like that, Maslahah orientation, and loyalty. This study will use 300 respondents who are customers of Sharia institutions. Islamic Bank. The questionnaire will contain questions related to the variables to be studied. In addition to the main data derived from the questionnaire, this study also uses secondary data as the basis for determining the research model, data processing and drawing conclusions. Secondary data comes from previous studies, which are summarized in several journals and official books relevant to the study.

In this study there will be 3 variables from 1 independent variable consisting of orientation to maslahah built with 5 dimensions that religion, orientationsoul mind orientation, descent and welth. In addition, this study also has one dependent variable which is customer loyalty and intermediation variable satisfaction. In the first stage the testing will be carried out on the instrument test, where the instrument test is carried out by testing the validity and reliability. Validity is usually related to whether the measuring instrument used is appropriate, whereas reliability is related to consistency, accuracy, predictability of the measuring instrument [24].

The analytical method used in this research is to use SEM (structural equation modeling) using the AMOS program and with the help of SPSS software. According to [25] SEM is a set of statistical techniques which allows testing a series of relatively complex relationships simultaneously. Hypotheses will be tested at an error rate of $5 \%$ and a significance level of $95 \%$. The reason for using SEM is its ability to confirm the dimensions of a concept or factor, and at the same time measure the influence or degree of association between identified factors [25].

3. Results and Analysis

Table 1 SEM processing results

\begin{tabular}{|c|c|c|c|c|c|c|}
\hline \multicolumn{3}{|c|}{ Hypothesis } & Estimate & S.E. & C.R. & $P$ \\
\hline Satisfaction & $\leftarrow$ & maslahah & .380 & .135 & 2,805 & .005 \\
\hline Loyalty & $\leftarrow$ & satisfaction & .076 & .151 & 2,503 & .046 \\
\hline Loyal ty & $\leftarrow$ & maslahah & 9132 & .179 & 7,345 & $* * *$ \\
\hline
\end{tabular}


The following are the results of testing the hypothesis according to table 1 above,

Hypothesis 1

This hypothesis will look at the effect of maslahah orientation on customer satisfaction. So that it will form the following hypothesis,

Ho: There is no effect of maslahah orientation on customer satisfaction.

$\mathrm{Ha}$ : There is an effect of maslahah orientation on customer satisfaction.

Based on table 1 of the test results above, it can be seen that the significance value is 0.005 where this value is less than $5 \%$ alpha so that $\mathrm{Ho}$ is rejected and $\mathrm{Ha}$ is accepted. Thus, it can be concluded that there is a significant effect of maslahah orientation on customer satisfaction. In table 2, the test results can also be seen that the coefficient estimate obtained is 0.27 , where this value shows that the effect of maslahah orientation on customer satisfaction is a positive effect which means that the higher the maslahah orientation in a company, the more satisfied it will be. the customer. In this coefficient it is also seen that the effect of maslahah orientation on customer satisfaction in Islamic banks is a weak influence.

This study is in accordance with the results of research from [23] where basically these previous studies are not exactly the same as this study but are confused, which means that these studies are studies that see the effect of applying gamma on customer satisfaction. .

\section{Hypothesis 2}

This hypothesis will look at the effect of maslahah orientation on customer loyalty. So that it will form the following hypothesis,

Ho: There is no effect of maslahah orientation on customer loyalty to Islamic institutions

$\mathrm{Ha}$ : There is an effect of ore crossed maslahah on customer loyalty to Islamic institutions.

Based on table 1 above, it can be seen that the significant value of this hypothesis is 0.005 where this value is less than alpha $5 \%$ so that $\mathrm{Ho}$ is rejected and $\mathrm{Ha}$ is accepted. Thus, it can be concluded that there is a significant influence between maslahah orientation in banking on customer loyalty.

Based on the table 2, there is also a beta coefficient value of 0.902 where this beta coefficient value shows a positive value so that it can be stated that the higher the orientation of the benefit felt by a customer, the more loyal the customer is. At the coefficient value, it can also be concluded that the influence given by this maslahah orientation on loyalty is very strong or in other words that there is a significant and very strong positive influence maslahah orientation on customer loyalty in Islamic banking in Jakarta. The results of this study are consistent with the results of research from [23], where these studies are studies that see the effect of the application of religious factors on customer satisfaction and loyalty.

\section{Hypothesis 3}

This third hypothesis will look at the effect of satisfaction on customer loyalty, so that it will form the following hypothesis,

Ho: there is no effect of customer satisfaction on customer loyalty in Islamic institutions

$\mathrm{Ha}$ : there is an effect of customer satisfaction on customer loyalty in Islamic institutions

By looking at table 1 above, it will appear that the significance value is 0.046 where this value is less than $5 \%$ alpha so that $\mathrm{Ho}$ is rejected and $\mathrm{Ha}$ is accepted, so that it will form a 
conclusion that there is a significant influence between customer satisfaction and customer loyalty of Islamic Institutions.

Table 2 Standardise direct effect

\begin{tabular}{|c|c|c|c|}
\hline & maslahah & satisfaction & loyalty \\
\hline satisfaction & .278 & .000 & .000 \\
\hline loyalty & .902 & .079 & .000 \\
\hline
\end{tabular}

Table 3 standardise indirect effect

\begin{tabular}{|c|c|c|c|}
\hline & maslahah & satisfaction & loyalty \\
\hline satisfaction & .000 & .000 & .000 \\
\hline loyalty & .022 & .000 & .000 \\
\hline
\end{tabular}

Hypothesis 4

This hypothesis will see the indirect effect of maslahah orientation on loyalty through customer satisfaction. Based on table 1, it can be seen that the effect of maslahah orientation on satisfaction is significant and the effect of satisfaction on loyalty is significant so that the effect of maslahah orientation on loyalty through satisfaction is significant. Furthermore, looking at table 4, the coefficient value of the indirect effect of maslahah orientation on loyalty is 0.02 , this value shows a very weak influence. This is due to the weak effect of satisfaction on loyalty [26].

\section{Discussion}

Benefit is a condition that every Muslim aspires to, even not only Muslims, basically everyone in the world will want this benefit, which is a condition in which a person is guaranteed his faith, physical and spiritual health, gets peace of mind, and guarantee for offspring and property. Implementation in obeying Allah SWT's orders in terms of achieving this Maqasid sharia is also stated in His Word as follows,

"Then We made you above a syari'at (regulation) regarding that matter (religion), so follow that syari'at and do not follow the lusts of people who do not know." [QS. Al-Maidah (5): 18].

In this research, the orientation of a Sharia Institution for the benefit of it is a very important factor. According to this study, orientation towards maslahah is a factor that has a significant and positive influence on customer satisfaction in Islamic banking. Furthermore, in this study, it was found that the orientation of maslahah is a capable factor in being able to build customer loyalty to Islamic institutions. This is in accordance with the verse from the word of Allah SWT as follows,

"And We sent down to you (Muhammad) the Holy Book (Al Qur'an) to explain everything and instructions and mercy and good news for those who surrendered" (Surah An Nahl, 16:89).

In this verse an understanding can be taken that everyone who tries to maintain and implement the sharia of Allah SWT will be given good news or it can be said in other words a joy or an advantage. This is in accordance with the results of this study because according to the results of this study, if the Islamic institution continues to maintain its orientation towards the maqasid of sharia, the customers will be more loyal to the institution. By looking at these results, it can be explained that for customers of Sharia Institutions, this benefit orientation is one of the most important factors for them and is one of the most powerful factors that customers consider to become customers at an Islamic institution in Jakarta. . 
Of course this is not surprising, because it is based on several similar previous findings, showing almost the same things, such as, [27] finding that general Islamic values such as halal / haram of products, honesty, humanity, and concern for religious activities such as (prayer times) provide a more positive perception of acceptance of services provided to Muslim consumers in Indonesia. And findings from [23] reveal that compliance with Islamic rules in Islamic institutions is very important for the development of relationship marketing in Islamic institutions. Although according to [28] which states that the influence of religiosity on a customer will be greatly influenced by how deep the person's understanding of his religious teachings is.

\section{Conclusion}

Based on this research, it is found that maslahah is a factor that can influence both directly and indirectly on customer loyalty. Maslaha is also a very important factor, if you look at the results in this study, it can be seen that the effect of maslahah on loyalty is much greater than the effect of maslahah on loyalty. These results indicate that the orientation to maslahah in an Islamic institution still needs to continue to be developed and improved, because it is one of the bases for the loyalty of customers at the institution but has not provided full customer satisfaction.

\section{Implications}

This study shows that orientation to maslahah is a very important factor for customer satisfaction and loyalty. For this reason, Sharia institutions should try to start developing the concept of maslahah orientation in these institutions so that they can attract more customers. In addition, based on the results of this study, it was found that the orientation of Islamic banking towards benefit has a very strong and positive and significant influence on customer satisfaction and loyalty in Jakarta. This can be used as a theory for subsequent researchers which, based on the authors' limited knowledge of previous research, have not conducted this kind of research.

\section{Limitations and suggestions}

In this study, the content of the maslahah orientation concept is still carried out through broad definition and identification. For future researchers, it is hoped that it can help develop this maslahah orientation by preparing a more detailed identification of the orientation concept of the maslahah.

\section{REFERENCE}

[1] S. Purnama, A. Sukmasari, and R. Bhandari, "The Role of Religiosity as a Mediating Variable in the Relationship between Online Transactions and Customer Satisfaction and Loyalty in Islamic Banking," Aptisi Trans. Manag., vol. 5, no. 2, pp. 143-151, 2021.

[2] S. Safriadi, "Kontribusi Ibn 'Āsyūr Dalam Kajian Maqāsid Al-Syarī'Ah," J. Ilm. Islam Futur., vol. 15, no. 2, p. 285, 2016.

[3] Y.-C. Chen, H.-H. Huang, S.-M. Chiu, and C. Lee, "Joint Promotion Partner Recommendation Systems Using Data from Location-Based Social Networks," ISPRS Int. J. Geo-Information, vol. 10, no. 2, p. 57, 2021.

[4] A. Mutakin, "Hubungan Maqashid Al Syari'Ah Dengan Metode Istinbath Hukum," Anal. J. Stud. Keislam., vol. 19, no. 3, pp. 547-570, 2017.

[5] B. Goud, T. A. Uddin, and B. A. Fianto, "2 Islamic Fintech and ESG goals," Islam. Fintech, p. 16, 2021.

[6] E. Depiana and H. Hartelina, "Marketing Service on Customer Satisfaction of Yamaha Motorcycles at PT Ramarayo Perdana Karawang," Aptisi Trans. Manag., vol. 5, no. 1, pp. 11-19, 2021.

[7] M. S. Siraj, "The Human Organ Transplantation Act in Bangladesh: Towards Proper Family-Based Ethics and Law," Asian Bioeth. Rev., pp. 1-14, 2021.

[8] N. Alsomali and G. Hussein, "CRISPR-Cas9 and He Jiankui's Case: an Islamic Bioethics Review using Maqasid al-Shari'a and Qawaid Fighiyyah," Asian Bioeth. Rev., pp. 1-17,

The Importance of Maslahah Orientation in Sharia Institutions (Primasatria Edastama) 
2021.

[9] M. MURSYID, H. KUSUMA, A. TOHIRIN, and J. SRIYANA, "Performance Analysis of Islamic Banks in Indonesia: The Maqashid Shariah Approach," J. Asian Financ. Econ. Bus., vol. 8, no. 3, pp. 307-318, 2021.

[10] J. Hom, B. Anong, K. B. Rii, L. K. Choi, and K. Zelina, "The Octave Allegro Method in Risk Management Assessment of Educational Institutions," Aptisi Trans. Technopreneursh., vol. 2, no. 2, pp. 167-179, 2020.

[11] A. M. Obeidat, "E-MARKETING AND ITS IMPACT ON THE COMPETITIVE ADVANTAGE," Elem. Educ. Online, vol. 20, no. 5, pp. 196-207, 2021.

[12] M. Abou-Shouk and M. Soliman, "The impact of gamification adoption intention on brand awareness and loyalty in tourism: The mediating effect of customer engagement," $J$. Destin. Mark. Manag., vol. 20, p. 100559, 2021.

[13] D. Gunawan and D. D. Arseto, "MEDIATION MODEL OF CUSTOMER LOYALTY SAMSUNG SMARTPHONE DURING PANDEMI COVID 19 USING WARP PLS," in Proceeding International Seminar of Islamic Studies, 2021, vol. 2, no. 1, pp. 571-577.

[14] A. Esmaeili, I. Haghgoo, V. Davidavičienè, and I. Meidutè-Kavaliauskienè, "Customer Loyalty in Mobile Banking: Evaluation of Perceived Risk, Relative Advantages, and Usability Factors," Eng. Econ., vol. 32, no. 1, pp. 70-81, 2021.

[15] P. Padeli, M. Mulyati, M. Faisal, and S. Debora, "E-CRM Mobile Applications To Improve Customer Loyalty (Case Study: PT Supermal Karawaci)," Aptisi Trans. Manag., vol. 4, no. 1, pp. 41-48, 2020.

[16] J. A. Martínez-González and C. D. Álvarez-Albelo, "Influence of Site Personalization and First Impression on Young Consumers' Loyalty to Tourism Websites," Sustainability, vol. 13, no. 3, p. 1425, 2021.

[17] S. Lee and J. Yoo, "Determinants of a Firm's Sustainable Competitive Advantages: Focused on Korean Small Enterprises," Sustainability, vol. 13, no. 1, p. 346, 2021.

[18] D. Zeren and A. Kara, "Effects of Brand Heritage on Intentions to Buy of Airline Services: The Mediating Roles of Brand Trust and Brand Loyalty," Sustainability, vol. 13, no. 1, p. 303, 2021.

[19] S. Alagarsamy, S. Mehrolia, and B. Singh, "Mediating Effect of Brand Relationship Quality on Relational Bonds and Online Grocery Retailer Loyalty," J. Internet Commer., pp. 1-27, 2021.

[20] F. Hussein and H. Hartelina, "After Sales Service For Smartphone Iphone To Customer Loyalty," Aptisi Trans. Manag., vol. 5, no. 1, pp. 62-72, 2021.

[21] A. Syafarudin, "The Effect of Product Quality on Customer Satisfaction Implications on Customer Loyalty in the Era Covid-19," Ilomata Int. J. Tax Account., vol. 2, no. 1, pp. 7183, 2021.

[22] X. Jia and Z. Chaozhi, "Turning impediment into attraction: A supplier perspective on Halal food in non-Islamic destinations," J. Destin. Mark. Manag., vol. 19, p. 100517, 2021.

[23] H. eddine Bedoui and W. Aaminou, "1 Role of Fintech to achieve the SDGs from an Islamic perspective," Islam. Fintech, p. 1, 2021.

[24] L. M. Graham, K. M. Sahay, C. F. Rizo, J. T. Messing, and R. J. Macy, "The validity and reliability of available intimate partner homicide and reassault risk assessment tools: A systematic review," Trauma, violence, Abus., vol. 22, no. 1, pp. 18-40, 2021.

[25] W. Ramadayanti and K. Kosasih, "The Influence of Financial Performance on People's Business Credit in Banking Companies for the Period 2010-2019," Aptisi Trans. Manag., vol. 5, no. 1, pp. 73-78, 2021.

[26] I. B. H. Murtiarso, Y. I. Graha, and N. Alnabawi, "Analysis of the Role of Quality on Job Satisfaction in Management with Sampling Techniques," Aptisi Trans. Manag., vol. 2, no. 1, pp. 28-36, 2018.

[27] A. Alam and L. Maknun, "Impact of Islamic Branding on Purchasing Decisions on Facial Wash Product," 2021.

[28] W. Yousef, P. Foroudi, S. Hussain, N. Yousef, T. C. Melewar, and C. Dennis, "Impact of the Strength of Religious Beliefs on Brand Love in the Islamic Market," Corp. Reput. Rev., pp. 1-18, 2021. 